\title{
The dimensions of accounting service quality
}

\section{Vitor Azzari ${ }^{1}$ (D) Emerson Wagner Mainardes ${ }^{2}$ E $\cdot$ Aziz Xavier Beiruth $^{2}$ (D) Fábio M. da $\operatorname{Costa}^{2}$ (D)}

Received: 5 December 2020 / Accepted: 23 June 2021 / Published online: 21 July 2021

(c) The Author(s), under exclusive licence to Springer Nature Switzerland AG 2021

\begin{abstract}
This study aimed to identify the dimensions of accounting service quality, as assessed by the different agents involved in service development. We performed 20 in-depth interviews with accounting service providers, clients of accounting service providers, consultants, university professors, and accountancy body members. The results revealed six dimensions of accounting service quality: advisory view, capability, efficiency, communication, technological innovation, and trustworthiness. We also identified the items corresponding to each of these dimensions. The results allowed us to develop a conceptual model of accounting service quality. This study also indicated the specificities of accounting services, demonstrating that general models for service quality assessment do not seem to fully fit the characteristics of the accounting context.
\end{abstract}

Keywords Service quality $\cdot$ Dimensions $\cdot$ Accounting $\cdot$ Service evaluation model

\section{Introduction}

Technological advances and the needs of new customers are changing the provision of accounting services and the engagement of accountants with their clients (Holm and Ax 2020; Khin et al. 2013; Lee et al. 2016). Services that previously were provided by structured professional accounting firms can now be performed

Emerson Wagner Mainardes

emerson@ fucape.br

Vitor Azzari

vitor.azzari@gmail.com

Aziz Xavier Beiruth

aziz@fucape.br

Fábio M. da Costa

fabio@fucape.br

1 FGV EAESP, São Paulo, SP, Brazil

2 FUCAPE Business School, Av. Fernando Ferrari, 1358, Boa Vista, Vitória, ES, Brazil 
using software. The covid-19 pandemic further increased these changes, generating digitization and automation of services (AICPA 2020). Thus, to maintain market share and penetration, accounting service providers need to improve their competitive strategies. This can be achieved with good management and a focus on delivering high-quality services (Fleischman et al. 2017).

However, delivering accounting services requires a high level of knowledge and highly skilled people (De Meyere et al. 2018; Santos-Vijande et al. 2013). Thus the factors that influence the customer's perception of quality may differ from the relevant factors in other sectors that theoretically provide less complex services (Doloreux and Laperrière 2014). The variations in customers' needs, sizes, and characteristics demonstrate the real difficulty for these professionals in achieving the quality expected by their clients (Santos and Spring 2015).

Service quality measurement tools can be used to assess customers' perceptions and needs, helping firms to improve their services. Models such as those of Cronin and Taylor (1992), Gronroos (1984), and Parasuraman et al. (1988) are still most commonly used for measuring service quality in various sectors (Roy et al. 2015). Accounting services are no different here. Even though there are only a few studies in the management accounting field that investigate service quality, these studies used these general models in the accounting context, obtaining results that differ from each other (e.g., Armstrong and Davision 1995; Botha and Wilkinson 2019; Fleischman et al. 2017; Guthrie and Parker 2016; Mutlu 2020; Souza et al. 2019; Stouthuysen et al. 2019).

The divergence in the results may be related to the fact that accounting has specific aspects, such as the important need for knowledge, the constant updating of standards, and the fact that there is service co-production with the different agents involved (Santos and Spring 2015). Thus, service quality models designed to be applied across a broad range of services may not fully capture the essence of accounting services (Aga and Safakli 2007).

For this reason, the objective of this study is to identify the dimensions of accounting service quality, as assessed by the different agents involved. For this purpose, twenty in-depth interviews were conducted with accounting service providers, clients of accounting service providers, consultants, university professors, and accountancy body members. The identification of attributes using different points of view allowed us to analyze different perceptions about the phenomenon.

This study makes theoretical contributions by presenting dimensions that emerged directly from the accounting context. Previous studies have used general measurement models such as SERVQUAL and SERVPERF (Azzari et al. 2020). These models were developed to be used in different service categories (Cronin and Taylor 1992; Parasuraman et al. 1988), and ignore the specific attributes of accounting services. Another contribution of this research is that it captures the standpoint of different stakeholders involved in the accounting services context. Previous studies focused on customers' perceptions of accounting firms (e.g., Lee et al. 2016; Sarapaivanich and Patterson, 2015; Silvestre et al. 2018). Even though this study did not aim to develop a measurement model for accounting service quality, it makes a first effort in this direction by generating dimensions and items that could be used in future studies. As presented by Boateng et al. 
(2018), the definition of each dimension and the generation of items are the first steps for scale development and validation.

This study also contributes to the work of accounting practitioners by expanding the discussion on the management of the quality of services. Many discussions in the accounting field are focused on technical and informational issues, and the aspect of delivering services in line with customer expectations is overlooked. Thus, our conceptual model tries to help accounting firms in their strategic decisions.

This article is structured as follows. Section 2 reviews the prior literature about service quality and the main measurement tools. Section 3 explains the details of the method used in this study. Section 4 presents the main results for each dimension that is explored. Section 5 provides a general discussion about the findings. Finally, Sect. 6 concludes this study.

\section{Literature review}

\section{Service quality}

The conceptualization of service quality can be divided into two schools: the Nordic school and the American one (Roy et al. 2015). The Nordic school combines the functional/technical elements and customer image. That is, it examines what services customers receive and how they receive them, emphasizing that the perception of quality is the outcome of the interaction between the consumer and the provider (Gronroos 1984; Lehtinen and Lehtinen 1991). On the other hand, the American school focuses on functional aspects, the mechanisms of this process, the intangible aspects of the service, and consumers' perception of quality as shaped by service delivery (Brady and Cronin 2001; Cronin and Taylor 1992; Parasuraman et al. 1985).

Besides the directions taken by the schools mentioned above, some different definitions of the quality of services have been created over time. According to Mitra and Golder (2006), service quality is a subjective judgment of the quality received from the service provider, measured against the expectation. Kamakura et al. (2002) describe service quality as objective and measurable, and free of intangible and extrinsic attributes such as the provider's behavior or brand image. Other studies, in turn, argue that word-of-mouth, customer perception of value, and price are attributes that can influence the perception of quality (Fleischman et al. 2017; Rao and Monroe 1989). However, Parasuraman et al. (1988) argue that the impact of price disappears when consumers have greater confidence in hiring a company's service through a third party's suggestions.

In any case, the treatment of service quality may change according to the context and the sector analyzed (Ladhari 2008). So-called Knowledge-Intensive Business Services (KIBS) - a category in which services such as those of law firms, architects, accountants, and advertising agencies are placed - have a greater need of a high level of knowledge, requiring the qualification and engagement of the team involved (Doloreux and Laperrière 2014; Santos-Vijande et al. 2013). The need for information also means that customer participation in the service development 
process has a direct impact on the quality of KIBS (Chiang and Trimi 2020; Santos and Spring 2015).

Specifically, studies of providers of accounting services, which is a type of KIBS, have sought to identify customer perceptions when determining service quality (Armstrong and Smith 1996; Fleischman et al. 2017; Sarapaivanich and Patterson 2015). Armstrong and Smith (1996) argue that internal and external factors influence the perception of accounting service quality. However, intangible external factors have a greater impact on consumers, demonstrating the importance of factors such as word-of-mouth and perceived professional quality.

Fleischman et al. (2017) argue that the technical aspects of accounting services are more important for the formation of perceived quality than the functional and image aspects. For Sarapaivanich and Patterson (2015), the consumer's level of experience with the KIBS needs to be considered. For clients with limited experience, the quality of interpersonal communication has a greater impact on their perceptions than the technical quality of the service provided. In line with these results, Sampet et al. (2019) argue that creating psychological comfort and stimulating consumer participation during audit services can have a positive impact on perceived quality and satisfaction.

\section{Service quality evaluation}

One of the most commonly used models for service quality measurement is SERVQUAL (Parasuraman et al. 1988). This model was developed to provide a general quality measurement for a wide variety of service categories. To generate the scale, its authors conducted 12 focus groups with consumers to assess their expectations and perceptions about the services provided by different companies (Parasuraman et al. 1988). Five main dimensions were found for the evaluation of the quality of services: (1) Tangibles: the appearance of physical facilities, equipment, and employees; (2) Reliability: the ability to perform the promised service reliably and accurately; (3) Responsiveness: the willingness to assist customers and provide prompt service; (4) Empathy: the provision of individual care and attention to clients; (5) Assurance: the knowledge and courtesy of employees and their ability to inspire confidence and security.

While SERVQUAL is one of the models that is most commonly referenced by different scientific studies to date, the applicability of a general model for all sectors and contexts has been questioned (Caro and García 2007; Fleischman et al. 2017; Ladhari 2008). Carman (1990) argues that some dimensions need expansion and that new items to capture the quality from different service sectors need to be included. It has been suggested that specific models for different service categories should be developed to identify all the specificities of a sector (Ladhari 2008).

Cronin and Taylor (1992) also develop justifications in their study that suggest that the concepts and operationalization of SERVQUAL are inadequate. For these authors, there is little theoretical evidence to prove that the gap between expectation and performance can be a relevant way to measure service quality. The so-called SERVPERF, Cronin and Taylor's (1992) alternative, is based on the assessment of 
customer perceptions or, in other words, on perceived performance. These authors point out that the quality of service predicts consumer satisfaction, which in turn has a significant impact on purchase intention (Cronin and Taylor 1992).

Even though Cronin and Taylor (1992) argue that their service quality assessment proposition is more consistent and adequate than SERVQUAL, SERVPERF has some limitations because of its weak generalizability in contexts, such as the provision of accounting services, in which there is a need for greater involvement by the company with its customers. Among the four sectors analyzed by the authors in their study (banking, pest control, laundries, and fast food), only the banking sector has this feature.

Even though this category of firms has been explored less thoroughly using Cronin and Taylor's (1992) model, previous studies have argued that service quality plays an important role in sectors that have a high need for consumer involvement (Roy et al. 2015; Seth et al. 2005). Specific measures for this type of services can reveal their quality more effectively than general models that apply to all types of service.

An analysis of studies over the years (Fig. 1) shows that researchers have commonly used the consumer's perception of the service delivered and its results, which, in turn, is based on the consumer's attitudes (Roy et al. 2015). Until now, the studies have been influenced by the concepts and dimensions used in the first models, such as that of Parasuraman et al. (1988). There has also been an increase in the number of studies that focus on specific contexts, and no further studies seeking to explore a number of categories of service in one generic model. As is said above, different contexts affect consumers' behavior and perceptions in different ways, which puts limits on broad and generic investigations that do not seek to understand the characteristics and details of each sector in the study (İçli and Anil 2014; Ladhari 2008).

Although studies have emerged that analyze specific sectors in detail, to the best of our knowledge no research has created a model for the context of professional accounting services. This gap contributes to the use by researchers of general dimensions and models, such as SERVQUAL and SERVPERF, in the accounting context, even though these models do not cover all the specificities of accounting services themselves. Aga and Safakli (2007), for example, used SERVQUAL to measure service quality and customer satisfaction in professional accounting firms. Their results indicate that only one of the five SERVQUAL dimensions had a statistically significant relationship with customer satisfaction. Lee et al. (2016) also used this instrument and found that all the five dimensions were relevant. On the other hand, Botha and Wilkinson (2019) used the SERVPERF instrument to evaluate the perceived value added by internal audit functions. They used service quality as a proxy and argued that the SERVPERF dimensions appear to be relevant to audit services.

These previous studies indicate the absence of pure models created specifically for professional accounting firms. Thus it becomes necessary to identify and explore the dimensions involved in the perception of quality in accounting services. 


\begin{tabular}{|c|c|c|}
\hline Models & Dimensions & Context \\
\hline $\begin{array}{l}\text { SERVQUAL } \\
\text { (Parasuraman, Zeithaml } \\
\& \text { Berry, 1988) }\end{array}$ & $\begin{array}{l}\text { Customers' expectations and perceptions about: tangibles, } \\
\text { reliability, responsiveness, assurance, and empathy. }\end{array}$ & General \\
\hline $\begin{array}{l}\text { SERVPERF (Cronin \& } \\
\text { Taylor, 1992) }\end{array}$ & $\begin{array}{l}\text { Customers' perceptions about: tangibles, reliability, } \\
\text { responsiveness, assurance, and empathy. }\end{array}$ & General \\
\hline $\begin{array}{l}\text { Retail Service Quality } \\
\text { (Dabholkar, Thorpe \& } \\
\text { Rentz, 1996) }\end{array}$ & $\begin{array}{l}\text { Physical aspects, reliability, personal interactions, problem- } \\
\text { solving, and policy. }\end{array}$ & Retailing \\
\hline $\begin{array}{l}\text { E-Service Quality } \\
\text { (Santos, 2003) }\end{array}$ & $\begin{array}{l}\text { Ease of use, appearance, linkage structure \& layout, content, } \\
\text { reliability, efficiency, support, communication, security, and } \\
\text { incentive. }\end{array}$ & Online stores \\
\hline $\begin{array}{l}\text { HEdPERF (Abdullah, } \\
\text { 2006) }\end{array}$ & $\begin{array}{l}\text { Non-academic aspects, academic aspects, reputation, } \\
\text { access, program issues, and understanding. }\end{array}$ & Education \\
\hline $\begin{array}{l}\text { EDUQUAL (Khan \& } \\
\text { Mahapatra, 2008) }\end{array}$ & $\begin{array}{l}\text { Learning outcomes, responsiveness, physical facilities, } \\
\text { personality development, and academics. }\end{array}$ & Education \\
\hline $\begin{array}{l}\text { E-S-QUAL } \\
\text { (Santouridis, Trivellas } \\
\text { \& Tsimonis, 2012) }\end{array}$ & Efficiency, system availability, fulfillment, and privacy. & $\begin{array}{l}\text { E-commerce } \\
\text { websites }\end{array}$ \\
\hline $\begin{array}{l}\text { FESTSERV } \\
\text { (Tkaczynski, 2013) }\end{array}$ & Human service, venue, and performance. & $\begin{array}{l}\text { Festivals and } \\
\text { special events }\end{array}$ \\
\hline $\begin{array}{l}\text { ISS-QUAL (Miller, } \\
\text { Hardgrave \& Jones, } \\
\text { 2013) }\end{array}$ & Service delivery, service product, and service environment. & $\begin{array}{l}\text { Information } \\
\text { systems } \\
\text { function }\end{array}$ \\
\hline $\begin{array}{l}\text { HEDQUAL (İçli \& } \\
\text { Anil, 2014) }\end{array}$ & $\begin{array}{l}\text { Academic quality, administrative services quality, library } \\
\text { services quality, support services quality. }\end{array}$ & $\begin{array}{l}\text { MBA } \\
\text { programs }\end{array}$ \\
\hline $\begin{array}{l}\text { M-S-QUAL (Huang, } \\
\text { Lin \& Fan, 2015) }\end{array}$ & $\begin{array}{l}\text { Contact, responsiveness, fulfillment, privacy, and } \\
\text { efficiency. }\end{array}$ & $\begin{array}{l}\text { Mobile } \\
\text { service }\end{array}$ \\
\hline
\end{tabular}

Fig. 1 Service quality assessment models

\section{Methods}

We applied a qualitative exploratory method through in-depth interviews. This method is appropriate, given that it was our objective to identify the dimensions of accounting service quality, based on different points of view (Creswell and Creswell 2017).

The interviews were all conducted in Brazil by the same researchers during March and May 2019. The respondents belonged to three major categories of respondents: accounting service providers, clients of accounting service providers, and accounting professors. Clients and providers have been studied as key 
players in service co-production (Santos and Spring 2015). The importance of knowledge and training for the provision of accounting services (Doloreux and Laperrière 2014) makes professors an interesting unit of analysis for this study.

The interviewees were chosen according to the ability of each of them to contribute to the discussion of the topic being explored, creating what is defined as a theoretical sample (Strauss and Corbin 1998). Besides playing different roles in the accounting area, the respondents also had heterogeneous characteristics in terms of gender, age, and location.

The nine professional accountants who participated in the interviews provided a wide variety of services: auditing, consulting, financial statement analysis, financial statement preparation, record-keeping, and tax accounting. Three of them had also devoted a significant part of their careers to working as the chair or deputy chair of an accountancy body. To differentiate them in our analyses, we labeled six of the professional accountants as 'Accountants', and the three with experience in accountancy bodies as 'Representatives'. Five clients who received a variety of accounting services were labeled as 'Clients'. Five accounting professors who had focused their careers on teaching and research were labeled as 'Professors'. Finally, one provider of accounting consulting services who was not a professional accountant was labeled as a 'Consultant'. We decided to interview only one consultant because this class is smaller than the others in the accounting environment. There are few consultants for accounting firms. The interview served to give an additional view of our research. It is important to note that consultants know several accounting firms and have a broader view of the service. While accountants and clients only know their own reality, a consultant can know the reality of different accounting service providers.

Table 1 presents a summary of the respondents and the role of each of the individuals interviewed.

The interviews were supported by a semi-structured questionnaire (Appendix A) based on certain topics, to guide our conversations with the interviewees. This began with more general aspects, and then explored more specific subjects based on the previous literature about accounting services and service quality. Thus, in these interviews, we captured opinions about different themes such as innovation (Chenhall and Moers 2015), the role of providers' knowledge (Doloreux and Laperrière 2014), customers' perceptions (Cronin and Taylor 1992), co-production, and the relationship between clients and service providers (Santos and Spring 2015). It is important to note that the semi-structured questionnaire had a guiding role. The interviewer was free to explore other subjects, depending on the progress of the conversation.

All participants received invitations prior to the interview that explained the general purpose of the study and presented all the ethical and confidentiality criteria related to the interviews. Also, the data were collected from each of the participants alone, to make them feel more comfortable and secure and so as to gather their real opinions. There was a preference for an in-person interview, but some were made by video call. The conversations lasted about $30-45 \mathrm{~min}$. In the later interviews, the emerging data were mostly similar to the previous ones. Thus, when we arrived at twenty interviews, we considered that we had reached theoretical saturation in the 


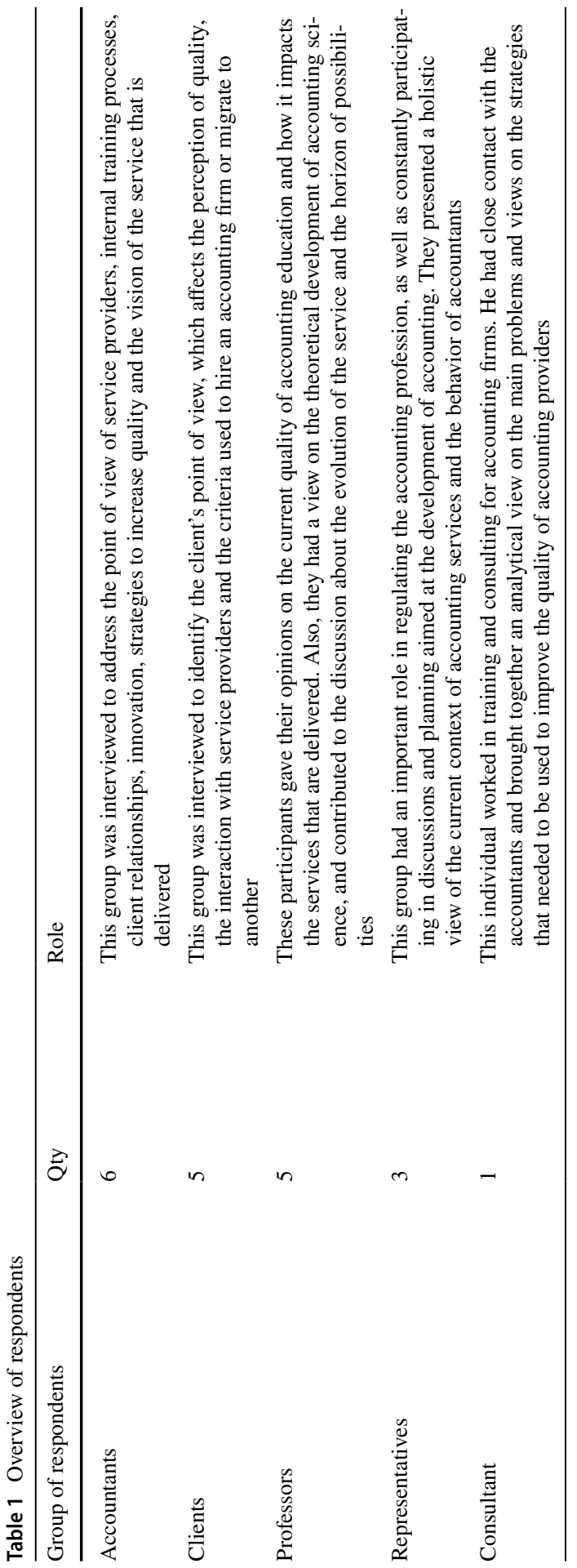


field. Also, the sample size of twenty interviews is aligned with the suggestions by Strauss and Corbin (1998) and Creswell and Poth (2016) for sample sizes in studies that seek to explore and generate new theories.

All the interviews were recorded and transcribed. The transcripts were entered into specific software for qualitative data analysis, NVivo. We used a coding technique to categorize the different concepts that emerged from the data (Flick 2014). Coding is defined as an operation to split data into small fragments to be conceptualized, and, after that, to be put together in new ways (Strauss and Corbin 1998). The same researchers who conducted the interviews also performed the coding procedures.

This process consisted of: (1) Analyze and codify phrase by phrase of interviews transcripts to identify several substantive categories or concepts. In this first step, the codification is more opened, based on researcher interpretation and previous knowledge about the theory. It is defined as open coding; (2) The second step consists in the axial coding, which the researcher makes the categories refinement by identifying and analyzing links and casual conditions between them; (3) Finally, in selective coding the researcher create a storyline to connect the categories (Creswell and Poth 2016). Thus, in our case, each theme category was an indicator and the links between the categories created the dimensions.

\section{Results}

First, we present a summary of the profile of each respondent in Table 2. We consider characteristics such as gender, level of education, background, and age. To preserve their identities, each respondent is identified using pre-defined letters (e.g., Client C).

When asked about what they understood about the general concept of quality, most respondents defined it as the providers' ability to meet the needs and deliver services of excellence to their clients. This definition is aligned with previous literature, which identifies quality as a concept that depends primarily on customergenerated expectations and the provider's ability to meet those expectations (Mitra and Golder 2006; Parasuraman et al. 1988).

On the other hand, some additional and specific elements were addressed by the interviewees when defining the quality of accounting services. For them, accounting services providers need to have an in-depth knowledge of the service, need to meet deadlines, and need to develop and maintain a partnership-like relation with their clients. These concepts are aligned with KIBS definitions, which highlights a greater need for a higher level of knowledge, beyond information sharing and co-production of the services (Doloreux and Laperrière 2014; Doloreux et al. 2019; Santos-Vijande et al. 2013; Santos and Spring 2015).

Respondents indicated that accounting services quality is a concept that has specific dimensions that are relevant for the overall perception of quality. This type of perception is also identified in previous service quality models, which used specific dimensions to measure quality in certain services. Therefore, by coding the 
Table 2 Interviewees' profiles

\begin{tabular}{|c|c|c|c|c|}
\hline Interviewee & Gender & Level of education & Study areas & Age \\
\hline Client A & Female & Doctorate degree & Economy & 56 \\
\hline Client B & Female & Postgraduate studies & Administration & 28 \\
\hline Client C & Male & Postgraduate studies & Engineering and Administration & 34 \\
\hline Client D & Male & Master's degree & Engineering and Administration & 31 \\
\hline Client E & Female & Master's degree & Administration & 27 \\
\hline Consultant A & Male & Postgraduate studies & Law and Administration & 32 \\
\hline Accountant A & Male & University graduate & Accounting & 34 \\
\hline Accountant B & Male & Postgraduate studies & Accounting & 57 \\
\hline Accountant $\mathrm{C}$ & Male & Postgraduate studies & Accounting & 26 \\
\hline Accountant D & Male & Master's degree & Accounting & 36 \\
\hline Accountant E & Male & University graduate & Accounting & 35 \\
\hline Accountant F & Female & Postgraduate studies & Accounting & 33 \\
\hline Professor A & Male & Doctorate degree & Accounting & 35 \\
\hline Professor B & Male & Doctorate degree & Accounting & 38 \\
\hline Professor $\mathrm{C}$ & Male & Doctorate degree & Accounting & 50 \\
\hline Professor D & Male & Doctorate degree & Accounting & 35 \\
\hline Professor E & Male & Doctorate degree & Accounting & 53 \\
\hline Representative A & Male & University graduate & Accounting & 72 \\
\hline Representative B & Male & Master's degree & Accounting & 38 \\
\hline Representative C & Male & Doctorate degree & Accounting & 65 \\
\hline
\end{tabular}

interviews, six main dimensions emerged from the data concerning accounting services quality.

The first one, labeled as the Advisory view, is characterized as the proactivity and the ability to interpret accounting information to identify opportunities and to advise clients in their decision-making processes. The second one, labeled as Capability, represents the level of knowledge and the continuous need for maintaining and further develop new knowledge. Efficiency considers the ability to be competent, productive, and to meet deadlines with minimal errors. Communication considers the exchange of information between the parties, as well as a clear and objective alignment about the service being provided. Technological innovation embraces the implementation of automated systems and processes, that facilitate and streamline activities that involve the provision of the service, eliminating unnecessary manual work. Finally, trustiness is the credibility of the service being provided.

Figure 2 presents the frequency in which the six dimensions were mentioned during the interviews. NVivo calculates this by considering the total of all encoded quotations that have been classified as each of the dimensions. The advisory view was the dimension most frequently addressed $(25 \%)$ by respondents - in other words, given all the interviews codifications, $25 \%$ of them were classified as an advisory view - followed by Capability (20\%) and Efficiency (20\%). Trustiness (4\%) was the dimensionless mentioned during the interviews. 


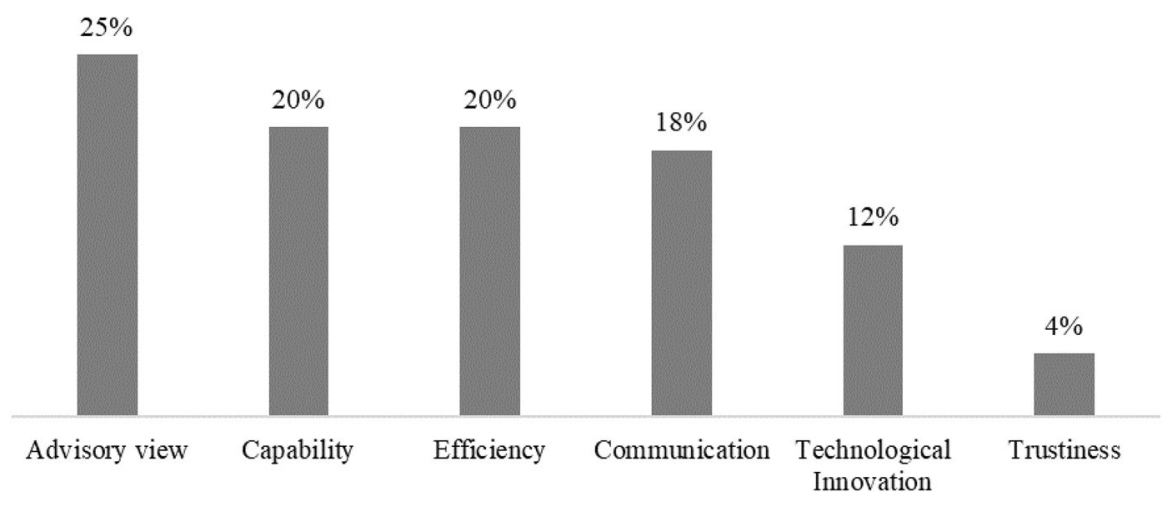

Fig. 2 Distribution of mentions by dimensions

Table 3 Codification per units of analysis

\begin{tabular}{|c|c|c|c|c|c|c|c|}
\hline & $\begin{array}{l}\text { Capability } \\
(\%)\end{array}$ & $\begin{array}{l}\text { Commu- } \\
\text { nication } \\
(\%)\end{array}$ & $\begin{array}{l}\text { Trusti- } \\
\text { ness } \\
(\%)\end{array}$ & $\begin{array}{l}\text { Efficiency } \\
(\%)\end{array}$ & $\begin{array}{l}\text { Technologi- } \\
\text { cal innova- } \\
\text { tion }(\%)\end{array}$ & $\begin{array}{l}\text { Advisory } \\
\text { view (\%) }\end{array}$ & Total (\%) \\
\hline Clients & 18 & 12 & 6 & 20 & 6 & 37 & 100 \\
\hline Consultant & 14 & 7 & 7 & 21 & 14 & 36 & 100 \\
\hline Accountants & 19 & 28 & 3 & 21 & 16 & 14 & 100 \\
\hline $\begin{array}{l}\text { Representa- } \\
\text { tives }\end{array}$ & 20 & 11 & 4 & 13 & 20 & 31 & 100 \\
\hline Professors & 19 & 25 & 3 & 18 & 15 & 21 & 100 \\
\hline
\end{tabular}

As discussed before, different types of respondents (consultant, accountants, representatives, clients, and professors) contribute to identifying different views of accounting services quality. Consequently, the focus and frequency of the dimensions that emerged through the interviews differ among the groups. We present the distribution of the number that each dimension was mentioned by each group in Table 3. This analysis uses the same frequency calculation method but dividing it by each interviewees' categories.

An overall analysis of the distribution presented in Table 3 highlights that there are convergences and divergencies when comparing the groups of respondents. Clients, consultants, and representatives focus more on the Advisory view dimension (over 30\%) while accountants and professors focus more on Соттиnication (28\% and 25\%, respectively). Efficiency was the second dimension that was most mentioned by clients, consultants and accountants (20\%, 21\%, and $21 \%$, respectively). The advisory view was ranked in second place for professors (21\%) while two dimensions achieved the same frequency for representatives: Capability and Technological Innovation (20\% each). Trustiness was the least mentioned dimension for all the types of respondents, ranging from 3 to $7 \%$ of the total. 
We discuss each dimension in detail, providing an in-depth analysis of the statements made by respondents, providing indicators for each one.

\section{Advisory view}

The advisory view was the dimension that was most mentioned during the interviews (25\% of the total). We present the indicators related to this dimension in Fig. 3.

Clients discussed the need for accountants to actively participate in the decisionmaking processes at the strategic level. Some of them even complained about the lack of proactivity of accounting services providers: "[...] for a range of services we have a percentage discount on some taxes, but I had to figure it out by myself. My accountant never informed me about this benefit." (Client C). One respondent used the term "strategic accounting" (Client B), highlighting the need for a professional accountant to be concerned about client's success.

The criticism raised above would be related to the need for professional accountants to shift from an operational view to a more strategic perspective. Some respondents discussed the need for accountants to develop new roles because of the ongoing process of service automation. In their point of view, professional accountants must interpret information, propose improvements, and actively assist in decision-making. Below is an excerpt from an interview:

I think the bookkeeping accountant profile will not survive. Because we already have many applications that will replace this part of the accounting service. Then the accountants will have to reinvent themselves. They need to understand that the role of accounting within the company has been expanded and it goes far beyond accounting reports. They must make those reports informational content that gives options for the firms' growth and investments. (Client A).

Consultant A discussed the same topic and indicated that the transition towards an advisory role is a new trend: "[...] there is a very large tendency to create a department within accounting organizations focused on customer success." Aligned with this view, representatives also see the need and opportunity for accountants to act embrace an advisory view:

But many accountants do a more technical job, and few who can even get a better financial result, with a better name, knowledge, and projection, are those who can align a technical job with management advisories. It allows you to bring a statement or report to your client, but it also allows you to bring suggestions and information to the decision-making process of organizations. (Representative C).

The discussions above are aligned with previous literature that an advisory role would be a key factor for the survival of the accountancy profession (Zimmerman 2015), advocating the role of providing not only analyses for financial information, but also related to company's products, market competition, and help on the 


\begin{tabular}{|c|c|}
\hline Items & Evidence \\
\hline $\begin{array}{l}\text { Proactivity in } \\
\text { proposing } \\
\text { practices that } \\
\text { generate } \\
\text { customer } \\
\text { benefits }\end{array}$ & $\begin{array}{l}\text { "My accountant doesn't give me any advice. For example: This money you can use } \\
\text { to do this investment." (Client A). } \\
\text { "The lack of tax guidance is also a factor that often occurs to generate these changes } \\
\text { of accounting providers." (Accountant B). } \\
\text { "[...] and also position himself as a strategic accountant, seeing what is happening } \\
\text { and try to help his customers proactively and not reactively." (Client B). }\end{array}$ \\
\hline $\begin{array}{l}\text { Delivery of } \\
\text { analytical } \\
\text { information }\end{array}$ & $\begin{array}{l}\text { "Companies that do not use this information and now they use it and realize that they } \\
\text { are starting to have better revenue, profitability, volume, cost, profit, etc." } \\
\text { (Representative B). } \\
\text { "There is a client that we do all the analysis of his company's information and make } \\
\text { a presentation every } 3 \text { months for him. So, I think it makes the customer more } \\
\text { satisfied." (Accountant C). } \\
\text { "The accountant not need only taking the number to his client orto whom he reports } \\
\text { the information, but also taking additional analysis to improve the client's decision } \\
\text { making." (Professor D). }\end{array}$ \\
\hline $\begin{array}{l}\text { Identification of } \\
\text { opportunities for } \\
\text { customer } \\
\text { improvement }\end{array}$ & $\begin{array}{l}\text { "We get closer to clients to grow management accounting and, in this way, they can } \\
\text { use this accounting in decision-making process" (Representative B). } \\
\text { "As companies grow, there is a need for all sectors to become strategic, so we have } \\
\text { an advisory accounting that helps us in decision making, fiscal, financial, etc." } \\
\text { (Client B). }\end{array}$ \\
\hline $\begin{array}{l}\text { Alert about } \\
\text { fiscal and } \\
\text { financial } \\
\text { dangers }\end{array}$ & $\begin{array}{l}\text { "The client needs to be informed of what has changed and what matters to him about } \\
\text { the law." (Representative A). } \\
\text { "Providing the ideal accounting service is take care of the business correctly and } \\
\text { always checking how the company is doing. Always alerting the company of the } \\
\text { possible dangers they may be facing." (Contador E). }\end{array}$ \\
\hline $\begin{array}{l}\text { Identification of } \\
\text { customers' } \\
\text { management } \\
\text { problems }\end{array}$ & $\begin{array}{l}\text { "The client is really starting to realize that he must have a good accounting tool to } \\
\text { solve his problems, especially management investment, or he will have a serious } \\
\text { problem, that's what we observe." (Representative A). } \\
\text { "If he wants to show me alternatives and /or errors in my management I like it too." } \\
\text { (Client A). }\end{array}$ \\
\hline $\begin{array}{l}\text { Interpretation } \\
\text { and analysis of } \\
\text { accounting } \\
\text { information }\end{array}$ & $\begin{array}{l}\text { "If you don't have a qualified person to understand these numbers and correct when } \\
\text { necessary, you will have trouble growing your business." (Accountant A). } \\
\text { "The client will go to an accounting professional to help understand the numbers and } \\
\text { what they mean, so that's what I think accountants will be dedicated to." (Professor } \\
\text { A). } \\
\text { "Someone needs to analyze this information. You have a processing machine, but } \\
\text { someone needs to interpret it because not everything has the right formula." } \\
\text { (Accountant D). }\end{array}$ \\
\hline
\end{tabular}

Fig. 3 Advisory view indicators 
implementation of a business strategy to support organizational decisions (Hutaibat 2019; Manyaeva et al. 2016).

Due to its more strategic nature, an advisory view can often be associated with clients with a more complex organizational structure. However, some excerpts from the interviews describe that this dimension is also necessary for small and mediumsized companies. As described by Representative B: "Micro and small businesses are unable to make adequate use of financial and economic instruments and the accountant needs to assist them in interpreting and using this information."

Also, small and medium enterprises cannot outsource consultants, and professional accountants can see it as an opportunity to expand their portfolio of services: "They can't afford to hire a good consultant. So, if the accountant fills that gap, he has a business opportunity there." (Consultant A). This perspective is aligned with the previous literature, indicating that smaller organizations usually have limited knowledge and need further help to improve their market share (Armitage et al. 2016).

Taken together, indicators for this dimension (Fig. 3) focus primarily on the capability of professional accountants to engage in solving a wider and more strategic set of client's challenges. This view is seen as the future role of accountant providers: "[...] There is an opportunity for accountants to demonstrate these potential additional services delivering better results and satisfaction for their clients and an opportunity for accountants to have a broader portfolio." (Professor C).

\section{Capability}

Accountants' capabilities represented $20 \%$ of the total topics mentioned during the interviews. This dimension is related to accountants' acquisition and maintenance of knowledge and is related to the Knowledge-Intensive Business Services (KIBS) literature, which focuses on the need for higher-level skills and knowledge, requiring continued professional education (Doloreux and Laperrière 2014; Santos-Vijande et al. 2013). Figure 4 presents interview quotes that highlight the presence of the indicators discussed for the development of the capability dimension.

During the interviews, aspects related to the acquisition of knowledge were discussed and considered topics such as accounting and legal matters, specialized skills, other technical skills, and participation in training and capacity-building programs. While accountants and representatives are aware of the need for constant knowledge updating, clients complained about the lack of technical knowledge.

Many interviewees argued that frequent updating of accounting Standards and other related legal matters require a process of continuous acquisition of knowledge by accountants to deliver accurate and reliable information. One type of activity is related to learnings processes based on continuous monitoring of changes in Standards and legislation. Updating knowledge is seen as either a self-paced learning process or via education programs. For example, one interviewee described the process in the following way: "Her job is to every morning check the legislation that was published in the official diary of that state that we have interest in dealing with taxes." (Representative A). Other interviewee argued that updating knowledge 


\begin{tabular}{|c|c|}
\hline Items & Evidence \\
\hline $\begin{array}{l}\text { Update on laws } \\
\text { and regulations }\end{array}$ & $\begin{array}{l}\text { "The accounting profession itself requires constant updating, due to changes in } \\
\text { legislation and accounting procedures. Thus, it requires constant updating of the } \\
\text { professional." (Professor B). } \\
\text { "[...] Keeping up to date with the standards and all legal aspects involved with the } \\
\text { standards that clients dealing with." (Professor C). } \\
\text { "There are some cases that the accountant is outdated, who did not keep up with } \\
\text { changes in legislation and the market. Because it is an area that changes all the time, } \\
\text { so updating is very necessary." (Client E). }\end{array}$ \\
\hline $\begin{array}{l}\text { Participation in } \\
\text { training and } \\
\text { qualifications }\end{array}$ & $\begin{array}{l}\text { "To solve this, the most experienced accountants need to train the least experienced } \\
\text { accountants." (Accountant C). } \\
\text { "[...]It would be to increase employee specialization, and that could be by applying } \\
\text { training too." (Client C). } \\
\text { "The accountants are not trained well. I think it takes a lot of good qualifications from } \\
\text { these accountants so that they can move forward and absorb this market." (Professor } \\
\text { E). }\end{array}$ \\
\hline $\begin{array}{l}\text { Technical } \\
\text { ability to } \\
\text { provide the } \\
\text { service }\end{array}$ & $\begin{array}{l}\text { "Customers analyze lot the technical capacity of the accountant a lot." } \\
\text { (Representative B). } \\
\text { "[...] I think it's for lack of technical knowledge. It is still an ending accountant } \\
\text { profile." (Client A). } \\
\text { "The client will only notice this lack of qualification in some meetings if he asks any } \\
\text { specific questions. But it makes a difference in the provision of the service, so if there } \\
\text { is any inspection, any statement, the unqualified accountant will have difficulty." } \\
\text { (Accountant F). }\end{array}$ \\
\hline $\begin{array}{l}\text { Adaptation to } \\
\text { nonroutine } \\
\text { demands }\end{array}$ & $\begin{array}{l}\text { "The other factor that I think is very important is whether that person will be able to } \\
\text { serve the client in something that goes beyond his routine and is very adverse, if he } \\
\text { will have the ability to do research and adapt." (Accountant A). }\end{array}$ \\
\hline $\begin{array}{l}\text { Knowledge } \\
\text { about the } \\
\text { client's activity }\end{array}$ & $\begin{array}{l}\text { "In our case, we work a lot with import and export companies [...], and we train } \\
\text { employees so that they also provide this service in a qualified manner in this sector." } \\
\text { (Accountant A). } \\
\text { "An accountant today serving industry and commerce, how is this professional going } \\
\text { to manage the various taxes and legislations involved in different types of clients? If } \\
\text { it focuses on a customer segment, it generates synergy in information, synergy to } \\
\text { build a foundation and assist the customer with accounting information." } \\
\text { (Accountant D). }\end{array}$ \\
\hline $\begin{array}{l}\text { Understanding } \\
\text { of customer } \\
\text { specificities }\end{array}$ & $\begin{array}{l}\text { "The distance from the professional with the specifics of the business. The } \\
\text { accountant has no idea what it is and what the customer needs, and then some } \\
\text { customers complained about these things when they came close with us." } \\
\text { (Accountant B). } \\
\text { "Pay more attention inside companies, then they will see the reality of companies. } \\
\text { Because today the accountant only knows what is on paper, does not know how it } \\
\text { acts. So, you know the day-to-day of the company will make a difference when } \\
\text { providing the service." (Accountant F). }\end{array}$ \\
\hline $\begin{array}{l}\text { Specialization in } \\
\text { an accounting } \\
\text { area. }\end{array}$ & $\begin{array}{l}\text { "What I also see is that accountants need to stop being generalists. Many accountants } \\
\text { seem to want to embrace the world and it turns out that the quality drops there. } \\
\text { Because he wants to know tax, accounting, personal department. But he needs to be } \\
\text { an expert in one area." (Accountant C). }\end{array}$ \\
\hline
\end{tabular}

Fig. 4 Capability indicators 
is based on a process of enrolling into formal education programs: "In our city, we have a partnership and every month we send some employees to update themselves" (Accountant B).

Accountants also need to be resilient to adapt to activities that often have details and nuances that may vary significantly. Accordingly, there is a need for accounting services providers to understand the peculiarities of their clients and often to specialize in fields such as auditing, budgeting, human resources, managerial, taxation, etc. For example, Accountant $\mathrm{C}$ discusses the need for specialization: " $[\ldots]$ accountants need to stop being generalists. Many accountants seem to want to embrace the world and it turns out that quality falls. Because he wants to know tax, accounting, human resource department."

Although updating of knowledge and specialization are factors that are relevant for accounting services providers, clients interviewed expressed their frustration with experiences that highlight the low-level of quality of some providers. For example, Client B, when talking about the calculation of employees' overtime, complained that: "We saw that these numbers are not matching with our numbers, but the accountant cannot explain this because he does not understand". And Client B continues: "[ $[.$.$] because one of the employees who assist us has already told us that$ she was not trained. So, a lot of basic stuff and sometimes a lot of basic mistakes is because the person was untrained." (Client B).

The discussion above highlights a potential gap between the ideal process of acquiring and maintaining technical and specialized knowledge and the negative experiences narrated by clients. Thus, consumers see an accountant's capabilities as a necessary characteristic to deliver a high-quality service.

\section{Efficiency}

Efficiency was defined by the interviewees as the accountant's ability to be competent, productive, and to be able to meet deadlines without errors. As indicators demonstrated in Fig. 5, this dimension fits into a more objective and tangible point of view, in line with the definition of service quality by Kamakura et al. (2002).

There is a primary focus on the basic fulfillment needs of that service. That is: "deliver something that has been agreed upon between the parties through a contract" (Professor C). On the other hand, some excerpts from the interviews also highlight the importance of accountants being flexible enough to be able to serve the client as they change in terms of activities and size (Represent C).

This dimension also extends the accountant's responsibility in meeting deadlines involving the service. According to McNeilly and Barr (2006), meeting deadlines and keeping promises are important competencies to delight customers in audit and accounting services. This was also present in our data. In services linked to taxation, which needs to perform certain procedures on dates set by public control agencies, the lack of care with such deadlines may directly impact the client's activities. Client $\mathrm{C}$, for example, exposed a situation where his company was harmed by such situations: 


\begin{tabular}{|c|c|}
\hline Items & Evidence \\
\hline $\begin{array}{l}\text { Flexibility to } \\
\text { meet different } \\
\text { types of } \\
\text { demands }\end{array}$ & $\begin{array}{l}\text { "A high-performance accounting service is that it is flexible enough to meet the needs } \\
\text { of different size customers." (Professor A). } \\
\text { "Quality in the accounting organization model works efficiently, it works by } \\
\text { observing a flexible organization structure." (Representative C). }\end{array}$ \\
\hline $\begin{array}{l}\text { Meeting } \\
\text { customer needs }\end{array}$ & $\begin{array}{l}\text { "If you think about accounting, a good service is one that best meets the specific need } \\
\text { for a good customer." (Professor A). } \\
\text { "It's the customer of the bar, it's the customer of the bakery, a smaller company, a } \\
\text { micro and such, he has no idea what he needs. So, if the accountant does the tribute } \\
\text { properly, the client will be } 100 \% \text { satisfied." (Professor E). }\end{array}$ \\
\hline $\begin{array}{l}\text { Fulfillment of } \\
\text { contracted } \\
\text { services scope }\end{array}$ & $\begin{array}{l}\text { "Achieving quality is only possible when clients and accountants both fulfill their } \\
\text { agreed responsibilities for service delivery, so it has to be a two-way street." } \\
\text { (Professor C). } \\
\text { "What I understand about the quality of service is that I get back the service I am } \\
\text { paying for and that is tied to a service contract." (Client C). } \\
\text { "Meet minimum service requirements." (Client D). }\end{array}$ \\
\hline $\begin{array}{l}\text { Error-free } \\
\text { service delivery }\end{array}$ & $\begin{array}{l}\text { "For this customer what's important? } 100 \% \text { correct, } 100 \% \text { correct information." } \\
\text { (Accountant D). } \\
\text { "When errors happen and penalize customers, it shows that the accountant did not } \\
\text { meet the required standard." (Professor E). } \\
\text { "What really impacts us is the issue of error, sending the wrong thing, etc." (Client } \\
\text { B 2019). }\end{array}$ \\
\hline $\begin{array}{l}\text { Delivery on } \\
\text { time }\end{array}$ & $\begin{array}{l}\text { "[...] Meet deadline for requests. Manage well the activity-related deadlines that are } \\
\text { in the hands of accounting." (Client C). } \\
\text { "Compliance with deadlines for services rendered is required." (Representative C) } \\
\text { "I think, first, meeting deadlines is critical." (Professor E) }\end{array}$ \\
\hline $\begin{array}{l}\text { Agility in } \\
\text { service } \\
\text { development }\end{array}$ & $\begin{array}{l}\text { "If he has no control, we deploy the controls so that he has his result ready by the } \\
15 \text { th of the following month. He has } 15 \text { days to have all the information processed to } \\
\text { can decide for the next } 15 \text { days, it is our differential here." (Accountant A) }\end{array}$ \\
\hline
\end{tabular}

Fig. 5 Efficiency indicators

[...] Manage well the activity-related deadlines that are in the hands of accounting. I'll give you a very practical example, we already had a problem here with the firemans expired license. My accountant didn't update the license. What impact of this from my activity? I cannot participate in any bidding. So, when I went to participate, I realized that the document was expired. (Client $\mathrm{C}$ ). 
Interviewees also emphasize the importance of accounting agility in providing information and delivering the service within a timeframe that not only meets the requirements of laws and regulations but also is comfortable for the client to use them to their advantage. It is expressed in the following excerpt: "The service is provided on time and not only within the legal timeframe but within the time required by the customer, the deadline that he understands that he must have the information and payment slips on his disposition." (Accountant B). It is important to accountants respect clients' time. Delivering service at the right time allowing a business to control the process flow to go undisturbed (McNeilly and Barr 2006).

Also, one of the most addressed indicators in the efficiency dimension concerns the correct and error-free service delivery, ensuring an intrinsic and technical quality of service. These errors could be usually caused by omission or lack of internal control (Burks 2015), and these aspects related to the service assurance will impact directly customer satisfaction and quality perception (Fleischman et al. 2017). Some respondents also pointed out how misdirected work can hurt contractors' firms by, for example, paying fines: "A bad experience for a client is thinking it's all right and getting a fine from years ago. You think everything is fine, everything is beautiful, and it happens." (Accountant D). Another respondent describes an information error situation that delays the entire course of business procedures: "What matters most is the error issue. We have been trying since November to run the union adjustment correction and we could not because we sent the information to the accountant and he sends it wrong to us." (Client B).

All these indicators that emerged from the data and which are linked to the efficiency dimension can be considered factors that directly impact the basic and technical expectations that the client has when hiring the accounting services. As stated earlier, there is a convergence of definitions highlighted by respondents about this dimension and the previously published literature on service quality, which defined it based on objective and technical characteristics (Fleischman et al. 2017; Gronroos, 1984; Kamakura et al. 2002). Given that, a constant focus and efforts to improve service efficiency could help accountants to meet the expectations of their clients with the services.

\section{Communication}

Communication is characterized by the exchange of information between the parties and the clear and objective alignment of the service being provided. This dimension also highlights practical aspects, such as the communication channels that are present during the service delivery, and abstract aspects, such as the importance of service and relationship to make the customer feel satisfied. Figure 6 points out each indicator that is part of the communication dimension.

A clear and transparent view of what is being delivered is considered fundamental when addressing any audience: "An informational clarification of what exactly the service you are offering and what the objectives and obligations. The accountant needs to be transparent at the time of service." (Professor B). Lack of clarity and alignment between the stakeholders can undermine the understanding of what is 


\begin{tabular}{|c|c|}
\hline Items & Evidence \\
\hline $\begin{array}{l}\text { Clear view on } \\
\text { the services } \\
\text { provided }\end{array}$ & $\begin{array}{l}\text { "Informational clarification on what exactly is the service you are offering and what } \\
\text { are the goals and obligations with it, the accountant needs to be transparent at the } \\
\text { time of service." (Professor B) } \\
\text { "The accountant will be able to provide mechanisms and instruments so that the } \\
\text { contractor can be clear about what his role as a client to achieve a higher service } \\
\text { quality." (Professor C) }\end{array}$ \\
\hline $\begin{array}{l}\text { Quick and easy } \\
\text { contact with the } \\
\text { accountant }\end{array}$ & $\begin{array}{l}\text { "The accountant needs two aspects of communication. The first is to communicate } \\
\text { with his client, the second is that he will be a communication channel between the } \\
\text { firm and the other users, so he depends a lot on communication." (Professor B) } \\
\text { "You have both an email and telephone communication channel, you need to have } \\
\text { proximity with the accountant." (Client B) }\end{array}$ \\
\hline $\begin{array}{l}\text { Exchange of } \\
\text { information } \\
\text { between the } \\
\text { parties }\end{array}$ & $\begin{array}{l}\text { "If he is away, he will have to request this information from the company, which in } \\
\text { turn will have to be aware that he has to get this information to work. So, this will } \\
\text { depend on the negotiations between the accountant and the company structures." } \\
\text { (Professor A) } \\
\text { "Because accounting today is not done in isolation. What would it be in isolation? } \\
\text { The client sends you all documentation and you will assemble the spreadsheets, }\end{array}$ \\
\hline & $\begin{array}{l}\text { reports and then return to him. Today accounting has to be unified: customer and } \\
\text { accountant." (Accountant E) }\end{array}$ \\
\hline $\begin{array}{l}\text { Treatment with } \\
\text { respect and } \\
\text { cordiality }\end{array}$ & $\begin{array}{l}\text { "[...] my accountant was disrespectful when I asked him about the service." (Client } \\
\text { A) } \\
\text { "I am hiring young, neither graduated or newly graduated. I say, "So you are the new } \\
\text { accounting. You need to develop a cordial treatment with customers and change their } \\
\text { perceptions." (Accountant D) } \\
\text { "I'm careful with these emails things. You have to write it right, cordially and } \\
\text { politely" (Accountant D) }\end{array}$ \\
\hline $\begin{array}{l}\text { Troubleshooting } \\
\text { through } \\
\text { conversations } \\
\text { with the } \\
\text { accountant }\end{array}$ & $\begin{array}{l}\text { "[...] and it is very common for those clients that we can maintain a closer } \\
\text { relationship, that they even bear the penalties for any failure, understanding the } \\
\text { circumstances of that." (Accountant B) } \\
\text { "My accountant knows a lot, but he already put himself in a different position from } \\
\text { never admitting he is wrong. So, sometimes happens to make mistakes and there is } \\
\text { an uncomfortable situation of him denying." (Client B) }\end{array}$ \\
\hline $\begin{array}{l}\text { Accountant } \\
\text { approach with } \\
\text { the customer }\end{array}$ & $\begin{array}{l}\text { "It is a practice we have here at least once a month to meet with those who have an } \\
\text { interest to visualize and understand why a certain value or situation has occurred in } \\
\text { his company." (Accountant A) } \\
\text { "I think it's the accountant being close to the customer, supporting what they need } \\
\text { when they have a question or want a suggestion." (Client C) }\end{array}$ \\
\hline
\end{tabular}

Fig. 6 Communication indicators 
being provided, thus reducing the perception accountant's relevance, especially for the clients that do not have specific accounting knowledge. Armitage et al. (2016) describe that companies with less complex structures have a greater difficulty understanding the usefulness of accounting techniques and services for their decisionmaking processes. Therefore, this lack of communication between the parties can lead to a "devaluation of the service and a poor perception of what is being provided" (Professor B).

Interviewees highlighted the importance of efficient communication among clients and accountants. As stated by Accountant E, "accounting is not done in isolation". Santos and Spring (2015) characterize Knowledge-Intensive Business Services as a type of service that should be produced between the parties. The authors argue that increased client cooperation through instruction and information exchange positively affects the quality of the services provided. The lack of this communication and information exchange can directly hinder the delivery of the accounting service, as exemplified in the following excerpt: "I have had problems in the past, for example, I would like to do untimely information work and everything, but the company did not send the necessary reports and documents on time. So, the work was never done the best way." (Accountant B). To create better integration between accountant professionals and clients is fundamental a high-quality communication (Payne et al. 2008).

Three indicators that were identified directly involve intrinsic aspects of customer service and the relationship between accountants and clients. The first indicator concerns the access between stakeholders. More than physical proximity, respondents emphasize the importance of a relationship that allows accountants to ask questions and indicate options for decision-making (Client C). Some interviewed accountants also exemplified actions that are taken to ensure this proximity: "I am a partner of an accounting organization that on Saturday we went out to visit clients. This is fundamental." (Representative A). "It is a practice that we have here at least once a month to meet with those who are interested in viewing and understanding why a certain value or situation has occurred in his company." (Accountant A). This can generate cooperation between clients and accountants led by communication (Knechel et al. 2020).

The second indicator is related to the accountants' ability to treat their clients politely, respectfully, and with cordiality. Client A, for example, addresses a negative experience: "[...] it was disrespectful when I covered him". Such indicators may directly impact the client's satisfaction with the service provided. The third indicator emphasizes how proximity generated by a good relationship between accountants and clients could help to quickly identify and adjust potential misalignments: "Because what often happens is that sometimes the client will make a complaint to the accountant and he will have the opportunity to talk and adjust what you are not happy within your service." (Professor C). Even though these aspects are not largely explored in management accounting literature, the customer relationship field emphasizes the importance to provide a better relationship with clients and how it can improve satisfaction with services (Verhoef 2003). 
Finally, interviewees highlighted the importance of communication to be fast between accountants and clients, taking into consideration the established communications channels and the response capability. For example:

You must have both an email and phone communication channel to make the decisions easier. But this needs to be in line with the availability of the accountant. There is no advantage in having communication channels if the accountant does not serve you when you need it (Client C).

Response capability is aligned with one of the SERVQUAL's dimensions (Parasuraman et al. 1988), which highlights prompt customer service. Excerpts related to this indicator show a more effective communication can be achieved through the diversity of communication channels used by the parties involved, and one of them is the in-presence meetings: “Today, for example, I went to clients' firms. So, we have to be always available to our clients." (Accountant D).

\section{Technological innovation}

For the interviewees, technological innovation mainly permeates the implementation of new automated systems and processes, that facilitate and assist in the development of activities. Figure 7 presents the indicators of the technological innovation dimension.

Data collected in this study identifies technology as a way to reduce time and costs: "Here, for example, we had a sector where we were in seven. And with everything being automated, this sector today has shrunk to three people" (Accountant A). New technologies can increase the volume, speed, and availability of processed data, making information analysis more robust and detailed (Bhimani and Willcocks 2014). Thus, this dimension must be an ally for accountants in improving their services.

The use of technology may also benefit the service provider when it reduces the likelihood of errors, as described by Consultant A: "Technology plays a role in validating customer data and reducing information errors." Güney (2014) highlights the increased credibility of accounting information when the service is supported by technology tools, making delivery more effective, affordable, and flexible for clients. Automation also makes it easier for the accountant to engage in analytical services that have higher added value for the clients, as described in the excerpt: "We have to automate tax relations as much as possible because today we work hard for tax authorities and little to the customer. Thus, there would be time to look more closely and with a managerial look at the client" (Accountant B).

One of the most cited technological innovations is the integration between the accountant, the government, and the client's systems, which facilitates the realtime sharing of relevant information between the parties. This exchange becomes fundamental for high-quality service development (Santos and Spring 2015). Besides, real-time data tracking can contribute for check information and verify possible divergences: 


\begin{tabular}{|c|c|}
\hline Items & Evidence \\
\hline $\begin{array}{l}\text { Systems } \\
\text { Automation }\end{array}$ & $\begin{array}{l}\text { "Some of my clients have import processes and others have processes that already } \\
\text { seek automatic importation." (Representative B) } \\
\text { "So, the automation of information helps us with this issue as well as time, because } \\
\text { if we were to do the work manually, we would spend a lot more time." (Accountant } \\
\text { A) }\end{array}$ \\
\hline $\begin{array}{l}\text { Reduction of } \\
\text { manual work }\end{array}$ & $\begin{array}{l}\text { "With the technology process and its development, the tendency is for manual } \\
\text { bookkeeping to cease to exist completely." (Representative B) } \\
\text { "So, the trend is that systems are getting better and better so that fewer people are } \\
\text { inserted in this context of entering information." (Accountant A) } \\
\text { "The next step is going to be replacing everything that can be automated by computer } \\
\text { anyway." (Client D) }\end{array}$ \\
\hline $\begin{array}{l}\text { Information } \\
\text { exchange by } \\
\text { digital means }\end{array}$ & $\begin{array}{l}\text { "As the customer also ends up participating in this type of operation, we can see } \\
\text { through numbers to see if the customer inserted any wrong information or not." } \\
\text { (Accountant A) } \\
\text { "A high-quality accounting service delivery today, in my view, is one that we have } \\
\text { extremely automated processes with digital information exchange" (Accountant B) }\end{array}$ \\
\hline $\begin{array}{l}\text { Real-time } \\
\text { access to } \\
\text { accounting } \\
\text { information }\end{array}$ & $\begin{array}{l}\text { "[...] So that we can look and see the business and the processes without much manual } \\
\text { operation, with more computerized and real-time operation. For me the future is } \\
\text { that." (Accountant B) } \\
\text { "Today the accountant has access to the financial system we use. He could use it } \\
\text { when needs some information, such as banking information, how much the partners } \\
\text { received, etc. This information he already has on the system, so it would speed up } \\
\text { the process." (Client B) }\end{array}$ \\
\hline $\begin{array}{l}\text { Use of } \\
\text { technological } \\
\text { tools in service } \\
\text { delivery }\end{array}$ & $\begin{array}{l}\text { "The professional is under pressure. Thus, he is obliged to seek the right tools and } \\
\text { technologies so that he can provide quality services." (Representative A) } \\
\text { "[...] But with regards to operationalization, bookkeeping, reporting and such, } \\
\text { technology tends to take over this flow." (Professor C) }\end{array}$ \\
\hline
\end{tabular}

Fig. 7 Technological innovation indicators

As the customer also ends up participating in this type of operation, we can see through numbers to see if the customer inserted any wrong information or not. Similarly, the customer can also analyze all the data and information being handled by the accountant (Accountant A). 
There is a general view that while technological tools will replace operational work, many accounting services cannot be parametrized (Zimmerman 2015), since the interpretation of data is still needed:

So, the tendency is that systems are getting better so that fewer people are inserted in this context of entering information. The system will be ready to give you certain information, however, it will be necessary to have people to signal and interpret the data. The tendency is that accounting does evolve in this technological area with systems improving to meet more accounting demands (Accountant B).

The data from interviews indicate that only there is general support for adopting new technological tools. Some interviews describe that accountants need to change their minds to understand how technological innovation can add value to their services: "We have a technological resistance when they offer us a good tool because we (accountants) think that it will be very expensive to implement. But we have to keep in mind that it is beneficial and adds greater value to the service." (Representative A). Others view technology as providing the possibility to meet specific customer needs: "[...] it can add to the increasing volume of processing of this data and information generating a greater diversity of reports according to the peculiarities and customer needs." (Professor C).

\section{Trustiness}

Trustiness was described by respondents as the credibility perceived by clients regarding accounting services being delivered. Moorman et al. (1992) define trust as a composite of beliefs about the benevolence, competence, honesty, and predictability of a trading partner, and is viewed as an essential element of successful relationships. Based on the interviews, we identified four indicators for this dimension presented in Fig. 8.

Accountants' reputation is relevant for clients when considering different service providers because the confidence in service delivered is greater, as described by Accountant A: "All our customers today, when they come to us, is because someone recommended us or our service to them.". This can be explained by the fact that accounting services require a high level of knowledge to deliver it in line with what customer expects (Santos-Vijande et al. 2013). Accountant D describes that the clients that had a good experience tend to make a recommendation of the same provider to others: "The customer is well served, has a good experience, and so on. Then you will build a customer portfolio based on that. The good experience ends up getting you more clients by referral."

The reliability of the information is another relevant indicator of trust. The generation and delivery of information, usually complying with law and regulations, is relevant for clients to understand their respective organizations (Zimmerman 2015). Therefore, the confidence that such information is being properly gathered, processed, and analyzed, becomes essential for the client: 


\begin{tabular}{|c|c|}
\hline Items & Evidence \\
\hline $\begin{array}{l}\text { Accountant } \\
\text { reputation }\end{array}$ & $\begin{array}{l}\text { "I used her reputation as a criterion. Because I didn't know of anyone complaining } \\
\text { about her services." (Client A) } \\
\text { "I think the accountant, like some other professions, get a lot of clients through } \\
\text { referrals. It is very difficult for you to look for an accountant in the newspaper, on } \\
\text { the internet or anything else. They will choose by nomination by other companies." } \\
\text { (Professor B) } \\
\text { "Most clients when they come to us usually look for a referral, someone who has } \\
\text { worked with us and refers us." (Accountant E) }\end{array}$ \\
\hline $\begin{array}{l}\text { Reliability of } \\
\text { information } \\
\text { generated }\end{array}$ & $\begin{array}{l}\text { "He needs to have an accounting that he can consider reliable or he will have } \\
\text { problems." (Representative A) } \\
\text { "If she wants a good accountant, she goes a lot on the reliability of the professional." } \\
\text { (Consultant A) } \\
\text { "And when we go to a company that has a greater sense of knowledge, I think they } \\
\text { even consider the reliability of the accountant" (Client E) }\end{array}$ \\
\hline $\begin{array}{l}\text { Security in } \\
\text { information } \\
\text { exchange }\end{array}$ & $\begin{array}{l}\text { "You need confidence to share all information openly with the accountant. Assuming } \\
\text { that he will not take advantage of it and that it will not fall into other hands." (Client } \\
\text { B) }\end{array}$ \\
\hline $\begin{array}{l}\text { Decision- } \\
\text { making advices }\end{array}$ & $\begin{array}{l}\text { "He seeks advice from an accounting professional or a lawyer who works with an } \\
\text { accountant. He sometimes looks for a good accountant, so this is proof that the } \\
\text { market is effectively changing." (Representative A) }\end{array}$ \\
\hline
\end{tabular}

Fig. 8 Trustiness indicators

High-quality accounting service is which we can trust in the provider. He will process and send you information, will generate financial and tax analysis, etc. Thus, you must be confident that the information will be right, he has not forgotten to do anything, and he has not calculated something wrong (Client B).

Information security is another indicator that was raised by interviewees since it will affect the co-production of the service between the client and the services provider: "You need the confidence to share all company information openly with your accountant. It must be assumed that he will not take advantage of it and that it will not fall into the hands of others." (Client B). With the technological advances of the last years, the concern with data security has become even greater (La Torre et al. 2018). The interviews indicate that not only the accountant but also the entire team involved in providing the service must take care to protect the company's information.

Finally, another indicator that emerged is how the credibility of the services providers encourages clients to ask for counseling. Counseling shows that clients rely on the knowledge of the service provider (Santos and Spring 2015) and contributes to deepening the relationship between the parties (Zimmerman 2015). 


\section{Discussion}

Results indicate that six dimensions are relevant for perceived quality in accounting services: advisory view, capability, efficiency, communication, technological innovation, and trustiness (Fig. 9). The model includes different aspects, such as strategic (advisory view), technical (efficiency and capability), intangible (trustiness and communication), and instrumental (technological innovation). The fact that such dimensions are not in line with the quality assessment models of previously developed scales demonstrating that accounting services, characterized as knowledgeintensive (KIBS), have specific characteristics that must be considered (Ladhari 2008).

Previous studies that aimed to investigate service quality aspects in the accounting context used generic models (e.g., Parasuraman et al. 1988). Because these models are not specifically related to accounting services, the studies obtained divergent findings (e.g., Botha and Wilkinson 2019; Fleischman et al. 2017; Guthrie and Parker 2016). Our results show that the accounting service dimensions have specific attributes that need to be observed by professionals who want to identify the quality of the service provided.

It is possible to identify an intersection with some of the dimensions that are present in the SERVQUAL model, such as reliability, responsiveness, empathy, and assurance (Parasuraman et al. 1988). These aspects can be observed in the communication, trustworthiness, and efficiency dimensions of the present study. On the other hand, other dimensions such as technological innovation and advisory view were not identified in models such as SERVQUAL (Parasuraman et al. 1988) or SERVPERF (Cronin and Taylor 1992). It can be shown that the generic tools capture only part of the accounting services phenomenon.

The fact that dimensions such as technological innovation and advisory view have not been identified in previous surveys of service quality assessments may demonstrate an evolution in accounting services management. Studies such as those by Lukka and Vinnari (2014) and Zyznarska-Dworczak (2018) address the shifting

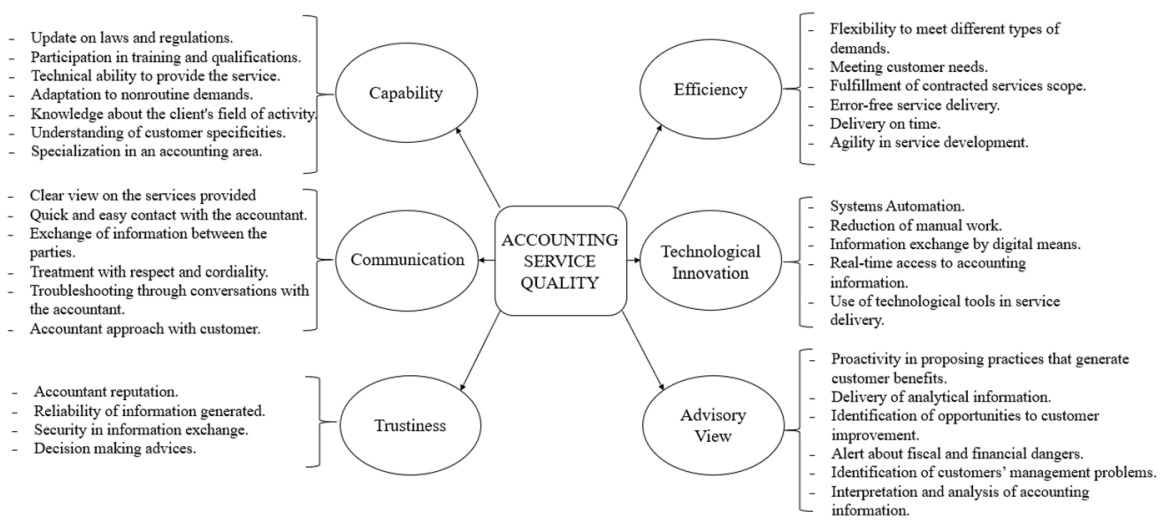

Fig. 9 Conceptual model 
focus of accounting over the years, with the purely technical view being set aside and the services being broadened to take a customer-oriented approach. Lee (2013) argues that if accounting firms are to keep pace with changing customer demand, a more aggressive and overt adjustment in the range of consulting and management services is required. This new approach to the quality of accounting services can be explained by the technological advances of recent years. It demonstrates that services that use human capital in an analytical and interpretative manner have a higher added value, given the change to the use of computerized systems for mechanical tasks (La Torre et al. 2018).

Another different aspect of the model compared to the previous service quality literature is the absence of tangible dimensions, such as the assessment of physical facilities and equipment, that are present in the SERVQUAL model of Parasuraman et al. (1988). This fact can be explained by the focus on the strong need for knowledge and co-production between the supplier and the customer in the provision of accounting services (Doloreux and Laperrière 2014), which means that the customer's expectation is that the services delivered will meet the accounting standards and laws and contribute to the evolution of the client's organization. In other words, the data that emerged from the interviews show a greater concern with results and intangible factors, since knowledge and information seem to be more important characteristics for accounting services. In a way, these results differ from those of Khin et al. (2011), who argue that the structures of accounting firms, such as physical infrastructure, are positively related to the performance of the services provided.

Models that sought to assess service quality in other sectors such as retail (Dabholkar et al. 1996) and festivals (Tkaczynski 2013), found some dimensions focusing on evaluating appearance and location. It is noteworthy that the retail sector and music festivals are not classified as KIBS, which may explain the focus on more tangible aspects for assessing quality.

Another difference found between this conceptual model and previous models concerns the difference in the perception of quality. The dimensions of the HEDQUAL model (İçli and Anil 2014), for example, which analyzes the quality of MBA programs, separated the quality assessment according to the different types of subservices provided: academic services, administrative services, library services, and support services. The ISS-QUAL (Miller et al. 2013) model for informational systems focused on dimensions that analyze the steps of the service process: service delivery, service product, and service environment. The dimensions of the quality of accounting services identified in this study, on the other hand, show that they align with the customer's perception of the service provision in general, encompassing the full range of accounting services (tax calculation, production of financial statements, tax management, reporting analysis, etc.) in a single mode of assessment, and bringing together the entire process, from contracting for the service and considering the reputation of the accountant (confidence indicator) to analyzing the results generated by the service (the advisory view dimension). This demonstrates that service quality models from different sectors may have different approaches: some consider the types of sub-services provided, others look at the service delivery process, and others make a combined analysis of all the aspects involved, which justifies the development of models of service quality for specific sectors, as is the case here. 
Given the above, the results found and systematized in Fig. 9 produce a model that is aligned with current discussions about the quality of accounting services for different actors. At the same time, the model has specific accounting characteristics that were not found in models that sought to investigate the quality of other service sectors, which corroborates the argument that service quality assessment tends to be more effective when a measurement tool is developed specifically for a particular service (İçli and Anil 2014).

\section{Conclusion}

The field of research into accounting service quality is still small, and divergent results have been found in previous studies for the elements that affect the perceived quality. This can be explained by the absence of a service quality model specifically created for this service (Azzari et al. 2020). Thus, in this study, we aimed to identify the dimensions of accounting service quality by hearing from the different actors involved in the process. It was possible to identify six dimensions: advisory view, capability, efficiency, communication, technological innovation, and trustworthiness. We can conclude that the quality of accounting services is a concept that involves aspects of a strategic, technical, instrumental, and intangible nature. These can be specifically analyzed by accountants to ensure the delivery of high-quality service.

This research generates theoretical contributions in the area. First, it contributes to the management accounting field by developing an accounting-specific service quality model, something that had not been previously developed, as previous studies have sought to apply the original or an adapted version of a generic service quality measurement model (as in Aga and Safakli 2007; Freeman and Dart 1993; Lee et al. 2016). Also, the study contributes by analyzing the quality of accounting services as seen from the different perspectives of the actors involved in the process, such as clients, accountants, professors, representatives, and consultants. Previous research on the quality of accounting services has focused on customer insights (Armstrong and Smith 1996; Khin et al. 2011; Lee et al. 2016; Sarapaivanich and Patterson 2015), ignoring the role of other stakeholders involved in the process. Finally, our results contribute to the future creation of a scale to measure accounting service quality. The first steps to develop a scale are domain identification and item generation (Boateng et al. 2018), and these steps have been taken in this study.

Among the practical implications, the study contributes to the expansion of the discussion about the quality of accounting services, an issue that is becoming increasingly important because of the contribution that quality can make to the generation of competitive advantages for accounting service providers (Sivakumar et al. 2014). Our results have important implications for the different actors involved in the accounting service process. By presenting the dimensions, the study can help accounting managers to generate evaluations and provide decisions for audit and accounting firms. Also, the six dimensions can serve as a reference to clarify the main aspects that a client needs to consider when contracting 
for accounting services. For academics, these results can help to expand and organize the academic discussion about the quality of accounting services in a structured way.

Among the research limitations, the study was exploratory and qualitative in nature. The identification and analysis of the dimensions of accounting service quality were developed from the perspective of twenty interviewees with experience in this area. The limited method and number of respondents affect the generalizability of the results of this study. Thus, the development of studies that statistically validate these dimensions in different contexts and environments of accounting services is recommended, allowing a statistical test of the model generated here and the generalization of the results. The indicators were developed on the basis of the codification of interviews. Therefore, we recommend applying quantitative strategies to validate the indicators in each of the presented dimensions.

The development of a model for accounting service quality expands the opportunities for studies related to the theme. One possibility is to analyze the proposed dimensions in different accounting business models, such as auditing, accounting and consulting firms. In this way, it would be possible to identify and compare the most relevant dimensions in the different accounting business models. Another opportunity concerns virtual accounting services and the types of clients that hire this service, to identify their perceptions about quality and satisfaction, and to try to profile companies that are best suited to online accounting. Finally, we suggest the development of a scale that measures the quality of accounting services and can be applied to case studies of failing and successful accounting firms, to assess the relationship between perceived quality and the performance of companies providing accounting services.

Supplementary Information The online version contains supplementary material available at https://doi. org/10.1007/s43546-021-00107-z.

Funding This research was supported by Brazilian National Council for Scientific and Technological Development (CNPq/Brazil), project 304209/2018-0, by Foundation for Research Support of Espírito Santo (FAPES/Brazil), projects 84513772 (599/2018) and 85395650 (228/2019), by Portuguese Science Foundation (FCT/Portugal) through NECE (Núcleo de Estudos em Ciências Empresariais), project UID/ GES/04630/2020, and by IFTS (Instituto Fucape de Tecnologias Sociais), project 2021-2024.

Data availability The data can be made available on request.

\section{Declarations}

Conflict of interest On behalf of all authors, the corresponding author states that there is no conflict of interest.

Informed consent At the beginning of the interviews, the researchers declared the study's purpose for the interviewees, sought the permission of their participation, assured the confidentiality of their information provided, and sought their permission of publication in journals, magazines, and periodicals. 


\section{References}

Aga M, Safakli OV (2007) An empirical investigation of service quality and customer satisfaction in professional accounting firms: evidence from North Cyprus. Probl Perspect Manag 5(3):84-98

AICPA (2020). Digital transformation reimagined: accountants' lessons learned and tips for moving forward. AICPA. https://future.aicpa.org/resources/download/digital-transformation-reimagined-accou ntants-lessons-learned

Armitage HM, Webb A, Glynn J (2016) The use of management accounting techniques by small and medium-sized enterprises: a field study of Canadian and Australian practice. Account Perspect 15(1):31-69. https://doi.org/10.1111/1911-3838.12089

Armstrong RW, Davision A (1995) An empirical investigation of the dimensions of service quality in Australian accounting firms. J Cust Serv Mark Manag 1(2):105-122. https://doi.org/10.1300/J127v 01n02_10

Armstrong R, Smith M (1996) Marketing cues and perceptions of service quality in the selection of accounting firms. J Cust Serv Mark Manag 2(2):37-59. https://doi.org/10.1300/J127v02n02_04

Azzari V, Mainardes EW, da Costa FM (2020) Accounting services quality: a systematic literature review and bibliometric analysis. Asian J Account Res 6(1):80-94. https://doi.org/10.1108/ ajar-07-2020-0056

Bhimani A, Willcocks L (2014) Digitisation, big data and the transformation of accounting information. Account Bus Res 44(4):469-490. https://doi.org/10.1080/00014788.2014.910051

Boateng GO, Neilands TB, Frongillo EA, Melgar-Quiñonez HR, Young SL (2018) Best practices for developing and validating scales for health, social, and behavioral research: a primer. Front Public Heal 6:1-18. https://doi.org/10.3389/fpubh.2018.00149

Botha LM, Wilkinson N (2019) A framework for the evaluation of the perceived value added by internal auditing. Med Acc Res 28(3):413-434. https://doi.org/10.1108/MEDAR-02-2019-0448

Brady MK, Cronin JJ (2001) Some new thoughts on conceptualizing perceived service quality: a hierarchical approach. J Mark 65(3):34-49. https://doi.org/10.1509/jmkg.65.3.34.18334

Burks JJ (2015) Accounting errors in nonprofit organizations. Acc Horizons 29(2):341-361. https://doi. org/10.2308/acch-51017

Carman JM (1990) Consumer perceptions of service quality: an assessment of the SERVQUAL dimensions. J Retail 66(1):33-55

Caro LM, García JAM (2007) Measuring perceived service quality in urgent transport service. J Retail Consum Serv 14(1):60-72. https://doi.org/10.1016/j.jretconser.2006.04.001

Chenhall RH, Moers F (2015) The role of innovation in the evolution of management accounting and its integration into management control. Acc Organ Soc 47:1-13. https://doi.org/10.1016/j.aos.2015. 10.002

Creswell JW, Creswell JD (2017) Research design: qualitative, quantitative, and mixed methods approaches. SAGE Publications Inc

Creswell JW, Poth CN (2016) Qualitative inquiry and research design: choosing among five approaches. SAGE Publications Inc

Cronin JJ, Taylor SA (1992) Measuring service quality: a reexamination and extension. J Mark 55(3):5568. https://doi.org/10.1177/002224299205600304

Dabholkar PA, Thorpe DI, Rentz JO (1996) A measure of service quality for retail stores: scale development and validation. J Acad Mark Sci 24(1):3-16. https://doi.org/10.1007/bf02893933

Doloreux D, Laperrière A (2014) Internationalisation and innovation in the knowledge-intensive business services. Serv Bus 8(4):635-657. https://doi.org/10.1007/s11628-013-0211-0

Edward K, Sek W, Singh G, Yee CM (2013) Strategic innovation of professional accounting firms to complete globally. Actual Probl Econ 145(7):261-267

Fleischman GM, Johnson EN, Walker KB (2017) An exploratory examination of management accounting service and information quality. J Manag Acc Res 29(2):11-31. https://doi.org/10.2308/jmar-51614

Flick U (2014) An introduction to qualitative research. SAGE Publications Inc

Freeman KD, Dart J (1993) Measuring the perceived quality of professional business services. J Prof Serv Mark 9(1):27-47. https://doi.org/10.1300/J090v09n01_04

Gronroos C (1984) A service quality model and its marketing implications. Eur J Mark 18(4):36-44. https://doi.org/10.1108/EUM0000000004784

Güney A (2014) Role of technology in accounting and e-accounting. Procedia - Soc Behav Sci 152:852855. https://doi.org/10.1016/j.sbspro.2014.09.333 
Guthrie J, Parker LD (2016) Whither the accounting profession, accountants and accounting researchers? Commentary and projections. Acc Audit Acc J 29(1):2-10. https://doi.org/10.1108/ AAAJ-10-2015-2263

Hutaibat K (2019) Accounting for strategic management, strategising and power structures in the Jordanian higher education sector. J Acc Organ Chang 15(3):430-452. https://doi.org/10.1108/ JAOC-06-2018-0054

Icli GE, Anil NK (2014) The HEDQUAL scale: a new measurement scale of service quality for MBA programs in higher education. South Afric J Bus Manag 45(3):31-43. https://doi.org/10.4102/ sajbm.v45i3.129

Kamakura WA, Mittal V, Rosa FD, Mazzon JA (2002) Assessing the service-profit Chain. Mark Sci 21(3):294-317. https://doi.org/10.1287/mksc.21.3.294.140Full

Khin EWS, Fatt CK, Heng TN (2011) Perception of Malaysian inland revenue board's tax audit service quality by SMEs. Actual Probl Econ 124:373-382

Knechel WR, Thomas E, Driskill M (2020) Understanding financial auditing from a service perspective. Acc Organ Soc 81:101080. https://doi.org/10.1016/j.aos.2019.101080

La Torre M, Botes VL, Dumay J, Rea MA, Odendaal E (2018) The fall and rise of intellectual capital accounting: new prospects from the big data revolution. Med Acc Res 26(3):381-399. https://doi. org/10.1108/MEDAR-05-2018-0344

Ladhari R (2008) Alternative measures of service quality: a review. Manag Serv Qual 18(1):65-86. https://doi.org/10.1108/09604520810842849

Lee CC (2013) Business service market share, international operation strategy and performance. Balt J Manag 8(4):463-485. https://doi.org/10.1108/BJM-02-2013-0020

Lee LT, Peng CS, Fan CK (2016) An empirical study of service quality: web service business transformation. Int J Comput Sci Eng 12(1):58-64. https://doi.org/10.1504/IJCSE.2016.074559

Lehtinen U, Lehtinen J (1991) Two approaches to service quality dimensions. Serv Ind J 11(3):287-303. https://doi.org/10.1080/02642069100000047

Lukka K, Vinnari E (2014) Domain theory and method theory in management accounting research. Acc Audit Acc J 27(8):1308-1338. https://doi.org/10.1108/AAAJ-03-2013-1265

Manyaeva V, Piskunov V, Fomin V (2016) Strategic management accounting of company costs. Int Rev Manag Mark 6(5):255-264

McNeilly KM, Barr TF (2006) I love my accountants - they're wonderful: understanding customer delight in the professional services arena. J Serv Mark 20(3):152-159. https://doi.org/10.1108/ 08876040610665607

Miller RE, Hardgrave BC, Jones TW (2013) ISS-QUAL: a measure of service quality for the information systems function. Inf Syst Manag 30(3):250-262. https://doi.org/10.1080/10580530.2013.794633

Mitra D, Golder PN (2006) How does objective quality affect perceived quality? Short-term effects, longterm effects, and asymmetries. Mark Sci 25(3):230-247. https://doi.org/10.1287/mksc.1050.0175

Moorman C, Zaltman G, Deshpande R (1992) Relationships between providers and users of market research: the dynamics of trust within and between organizations. J Mark Res 29(3):314. https://doi. org/10.2307/3172742

Parasuraman A, Zeithaml VA, Berry LL (1985) A conceptual model of service quality and its implications for future research. J Mark 49(4):41-50. https://doi.org/10.1177/002224298504900403

Parasuraman A, Zeithaml VA, Berry LL (1988) SERVQUAL: a multiple-item scale for measuring consumer perceptions of service quality. J Retail 64(1):12-40. https://doi.org/10.1016/S0148-2963(99) 00084-3

Payne AF, Storbacka K, Frow P (2008) Managing the co-creation of value. J Acad Mark Sci 36(1):83-96. https://doi.org/10.1007/s11747-007-0070-0

Rao AR, Monroe KB (1989) The effect of price, brand name, and store name on buyers' perceptions of product quality: an integrative review. J Mark Res 26(3):351. https://doi.org/10.2307/3172907

Roy SK, Lassar WM, Ganguli S, Nguyen B, Yu X (2015) Measuring service quality: a systematic review of literature. Int J Serv Econ Manag 7(1):24-52. https://doi.org/10.1504/IJSEM.2015.076322

Sampet J, Sarapaivanich N, Patterson P (2019) The role of client participation and psychological comfort in driving perceptions of audit quality: evidence from an emerging economy. Asian Rev Acc 27(2):177-195. https://doi.org/10.1108/ARA-09-2017-0144

Santos JB, Spring M (2015) Are knowledge intensive business services really co-produced? Overcoming lack of customer participation in KIBS. Ind Mark Manag 50:85-96. https://doi.org/10.1016/j.indma rman.2015.04.005 
Santos-Vijande ML, González-Mieres C, López-Sánchez JÁ (2013) An assessment of innovativeness in KIBS: implications on KIBS' co-creation culture, innovation capability, and performance. J Bus Ind Mark 28(2):86-102. https://doi.org/10.1108/08858621311295236

Sarapaivanich N, Patterson PG (2015) The role of interpersonal communication in developing smallmedium size enterprise (SME) client loyalty toward an audit firm. Int Small Bus J Res Entrep 33(8):882-900. https://doi.org/10.1177/0266242614524259

Seth N, Deshmukh SG, Vrat P (2005) Service quality models: a review. Internat J Qual Reliabil Manag. https://doi.org/10.1108/02656710510625211

Sivakumar K, Li M, Dong B (2014) Service quality: the impact of frequency, timing, proximity, and sequence of failures and delights. J Mark 78:41-58. https://doi.org/10.1509/jm.12.0527

Strauss A, Corbin J (1998) Basics of qualitative research techniques. SAGE Publications Inc

Tkaczynski A (2013) Festival performance (FESTPERF) revisited: service quality and special events. Adv Hosp Leis 9(1):227-235. https://doi.org/10.1108/S1745-3542(2013)0000009015

Verhoef PC (2003) Understanding the effect of efforts on customer retention and customer share development. J Mark 67:30-45

Zimmerman JL (2015) The role of accounting in the twenty-first century firm. Acc Bus Res 45(4):485509. https://doi.org/10.1080/00014788.2015.1035549

Zyznarska-Dworczak B (2018) A research note of potential scientific management accounting research area in CEECs. J Acc Manag Inf Syst 12(2):252-265. https://doi.org/10.24818/jamis.2018.02004 